\title{
REMOVAL OF GAS-PHASE BENZENE IN AN IMMOBILIZED PHOTOCATALYTIC REACTOR
}

\author{
Krishnan Jagannathan ${ }^{1 *}$ and Tyagarajan Swaminathan ${ }^{2}$ \\ ${ }^{1}$ Faculty of Chemical Engineering, Universti Teknologi MARA, \\ Shah Alam - 40450, Selangor Darul Ehsan, Malaysia \\ ${ }^{2}$ Department of Chemical Engineering, Indian Institute of Technology Madras, \\ Chennai- 600 036, Tamilnadu, India \\ *jagannathan@salam.uitm.edu.my
}

\begin{abstract}
The photocatalytic degradation of gas-phase benzene was studied in an immobilized - annular tube reactor using titanium dioxide as the photocatalyst. The main and interaction effects due to the influence of essential process parameters such as catalyst load $\left(5\right.$ to $\left.20 \mathrm{~g} \cdot \mathrm{m}^{-2}\right)$, benzene concentration $\left(0.2-3.1 \mathrm{~g} \cdot \mathrm{m}^{-3}\right)$ and flow rate $\left(0.2\right.$ to $11 \cdot \mathrm{min}^{-1}$ corresponding to residence times of $14 \mathrm{~s}$ and $70 \mathrm{~s}$ respectively) on the removal of benzene were investigated, by carrying out experiments that were designed to express statistical significance. The main effects plot and Pareto plot provided good insight into the effect of different parameters on the removal of gas-phase benzene. A new, statistical measurement suggests that low gas-phase benzene concentration is more important for maintaining high removal efficiencies $(96 \%)$ in the photocatalytic reactor than both catalyst load and flow rate.
\end{abstract}

Keywords: photocatalysis; gas-phase benzene; titanium dioxide; immobilized photoreactor; statistically designed experiments

\section{ОТСТРАНУВАЊЕ НА БЕНЗЕН ВО ГАСНА ФАЗА ВО НЕПОДВИЖЕН ФОТОКАТАЛИТИЧКИ РЕАКТОР}

Фотокаталитичкото распаѓање на бензен во гасна фаза е следено во неподвижен кружноцевчест реактор со користење на титандиоксид како фотокатализатор. Следени се главните, како и ефектите од интеракцијата како резултат на влијанието на есенцијалните процесни параметри: каталитичкото полнење (5 до $\left.20 \mathrm{~g} \cdot \mathrm{m}^{-2}\right)$, концентрацијата на бензен $\left(0,2-3,1 \mathrm{~g} \cdot \mathrm{m}^{-3}\right)$ и брзината на проток (0.2 до $11 \cdot \mathrm{min}^{-1}$, што соодветствуваат на време на престој од 14 и 70 секунди, соодветно) врз отстранувањето на бензенот преку изведување на експерименти кои се дизајнирани за да се изрази статистичката значајност. Графикот на главните ефекти и графиконот на Парето овозможуваат добар увид во ефектите на различни параметри врз отстранувањето на бензенот во гасна фаза. Новото статистичко мерење укажува дека ниската концентрација на бензенот во гасна фаза е позначајна за одржување на висока ефикасност на отстранување (96 \%) во фотокаталитичкиот реактор одошто каталитичкото полнење и брзината на проток.

Клучни зборови: фотокатализа; бензен во гасна фаза; титандиоксид; неподвижен фотореактор; статистички дизајнирани експерименти 


\section{INTRODUCTION}

The dramatic and debilitating effects of air pollution are a matter of increasing regulatory concern. The 1990 Clean Air Act Amendments, proposed by the USEPA is the most recent version of a law that was originally passed in 1970 to clean up air pollution. Among the different volatile organic compounds mentioned in the CAAA - 1990, benzene is one of the most commonly emitted VOC from printing offices, automobiles, petrochemical plants, petroleum tanks, coke ovens, distillation towers and from industrial facilities where benzene is used as a solvent. On the other hand, benzene has shown to cause severe health problems and environmental - related issues, due to their carcinogenic nature as well as their tendency to form secondary pollutant, viz., ozone by reacting with $\mathrm{NO}_{x}$ in the presence of sunlight at the ground level. Breathing high levels of benzene can result in central nervous system damage, while low levels can cause dizziness, rapid heart rate, headaches, vomiting and unconsciousness [1]. Among various treatment methods developed for the degradation of VOCs, that includes chemical and biological treatment systems and (or) a combination of both, photocatalytic oxidation process appears to be a highly effective technology to decompose high concentrations of VOCs to harmless end products such as $\mathrm{H}_{2} \mathrm{O}$ and $\mathrm{CO}_{2}$ at ambient temperatures [2]. Recently, the gas-phase elimination of VOCs in photo reactors using suitable photocatalyst such as $\mathrm{TiO}_{2}$ has received increased attention in process industries [3]. $\mathrm{TiO}_{2}$ irradiating with UV or near UV light results in the formation of electron-hole pairs on the catalyst surface. These electrons and holes interact with adsorbed species producing highly reactive hydroxyl radicals which in turn initiate redox reactions to decompose VOCs. It is known from the literature elsewhere that, shorter the wavelength more is the degradation potential of VOCs in the photoreactor.

Photoreactors of various configurations have been developed to serve a wide variety of purposes and mainly for cleaning a polluted environment. However, annular fixed-bed reactors with $\mathrm{TiO}_{2}$ coated on the surface of reactor wall are the most commonly employed photoreactors owing to their ease of construction and operation [4, 5 and 6]. The removal efficiencies reported in the literature for a few VOCs in different types of photoreactors employing $\mathrm{TiO}_{2}$ and $\mathrm{UV}$ radiation are listed in Table 1.

T a b l e 1

Removal efficiencies reported for a few VOCs in the literature

\begin{tabular}{|c|c|c|c|c|c|}
\hline $\begin{array}{l}\text { S. } \\
\text { No }\end{array}$ & VOC studied & Photoreactor used & $\begin{array}{l}\text { Concentration } \\
\text { range }\end{array}$ & $\begin{array}{l}\text { Removal } \\
\text { efficiency, \% }\end{array}$ & Reference \\
\hline 1 & Benzene & $\begin{array}{l}\text { Continuous, fixed-bed }\left(\mathrm{TiO}_{2}\right) \text { flow mi- } \\
\text { croreactor, } 8 \mathrm{~W}, 365 \mathrm{~nm}\end{array}$ & 860 ppmv & 16.8 & 7 \\
\hline 2 & Ethylene & $\begin{array}{l}\text { Tubular, packed with } \mathrm{TiO}_{2} \text { coated glass } \\
\text { ring, } 8 \mathrm{~W}, 365 \mathrm{~nm}\end{array}$ & 48.99 ppmv & $10.7-24.3$ & 8 \\
\hline 3 & Propan-2-ol & $\begin{array}{l}\text { Tubular, packed with } \mathrm{TiO}_{2} \text { coated glass } \\
\text { fibre, } 400 \mathrm{~W}, 280-450 \mathrm{~nm}\end{array}$ & $23.1-68.3 \mathrm{~g} / \mathrm{m}^{3}$ & $1.9-11.2$ & 9 \\
\hline 4 & Toluene & $\begin{array}{l}\text { Tubular, packed with } \mathrm{TiO}_{2} \text { coated glass } \\
\text { fibre, } 400 \mathrm{~W}, 280-450 \mathrm{~nm}\end{array}$ & $18.7 \mathrm{~g} / \mathrm{m}^{3}$ & $1.6-9.1$ & 9 \\
\hline 5 & Toluene & $\begin{array}{l}\text { Tubular, } \mathrm{TiO}_{2} \text { coated photoreactor, } 4 \mathrm{~W} \text {, } \\
254+185 \mathrm{~nm}\end{array}$ & $0.6 \mathrm{ppmv}$ & 84 & 10 \\
\hline 6 & Toluene & $\begin{array}{l}\text { Non cylindrical photoreactor fitted with } \\
\mathrm{TiO}_{2} \text { coated fabric, } 370+250 \mathrm{~nm}\end{array}$ & 7 ppmv & $7-25$ & 11 \\
\hline 7 & Vinyl chloride & $\begin{array}{l}\text { Tubular, } \mathrm{TiO}_{2} \text { coated with silica support, } \\
254+185 \mathrm{~nm}\end{array}$ & $160 \mathrm{ppmv}$ & 80 & 12 \\
\hline
\end{tabular}

From NIOSH manual, C, ppmv $=\mathrm{C}, \mathrm{g} / \mathrm{m}^{3} \times 24460 / \mathrm{M}$ 
Application of statistical design of experiments in process development can lead to improved yield of a process, reduced process variability, reduced development time and overall costs, besides providing valid, meaningful and objective conclusions. Statistical methodology plays significant role in analyzing the data where there is a chance of experimental errors [13]. During lab scale investigations, the most commonly done routine is to study the effect of two or more factors/parameters on a response variable. Under such a case, the classical method of studying one parameter at a time can be inefficient and also needs very extensive experimental work. Factorial designs are widely used in such instances that involve several factors, where it is necessary to study the interactions effect of the factors on the final response. The two-level full factorial design, which is most popular, includes all possible factor combinations at two levels, low and high, for each of the factors.

This paper reports the use of $2^{k}$ factorial design to study the effect of process parameters on the removal of benzene by $\mathrm{UV} / \mathrm{TiO}_{2}$ process in the annular immobilized photoreactor. The main and interaction effects were analyzed for their statistical significance by performing ANOVA.

\section{MATERIALS AND METHOD}

\subsection{Chemicals}

Benzene (99\% purity, Ranbaxy chemicals, India) and $\mathrm{TiO}_{2}(\mathrm{CDH}$ Chemicals, primarily anatase, surface area: $15 \mathrm{~m}^{2} \cdot \mathrm{g}^{-1}$ ) were used without further purification.

\subsection{Analytical measurements}

Gas-phase benzene concentration was measured with a gas chromatograph (Nucon Eng., India) using a Chromatopak column (1/8" ID, liquid - $3 \%$ Dexil, solid - Ch-W (AW), 80/100 mesh) and a flame ionization detector. Nitrogen was used as the carrier gas. The temperatures of the injection port, oven and detection port were 200,55 and $210^{\circ} \mathrm{C}$, respectively.

\subsection{Reactor configuration}

The schematic of the experimental setup is shown in the Figure 1. The annular photoreactor consisted of a cylindrical tube, $3.7 \mathrm{~cm}$ inner diameter and $43 \mathrm{~cm}$ long, coated on the inner surface with $\mathrm{TiO}_{2}$. The UV irradiation was provided by a $15 \mathrm{~W}$ tubular UV lamp, $2.6 \mathrm{~cm}$ in diameter and $43.5 \mathrm{~cm}$ long, mounted centrally in the reactor using the light fitting end caps, giving an effective annular volume of $234 \mathrm{ml}$. The UV lamp emitted predominantly at $254 \mathrm{~nm}$ and its intensity measured by Lutran digital radiometer was found to be $7 \mu$ Einstein $\mathrm{m}^{-2} \cdot \mathrm{s}^{-1}$.

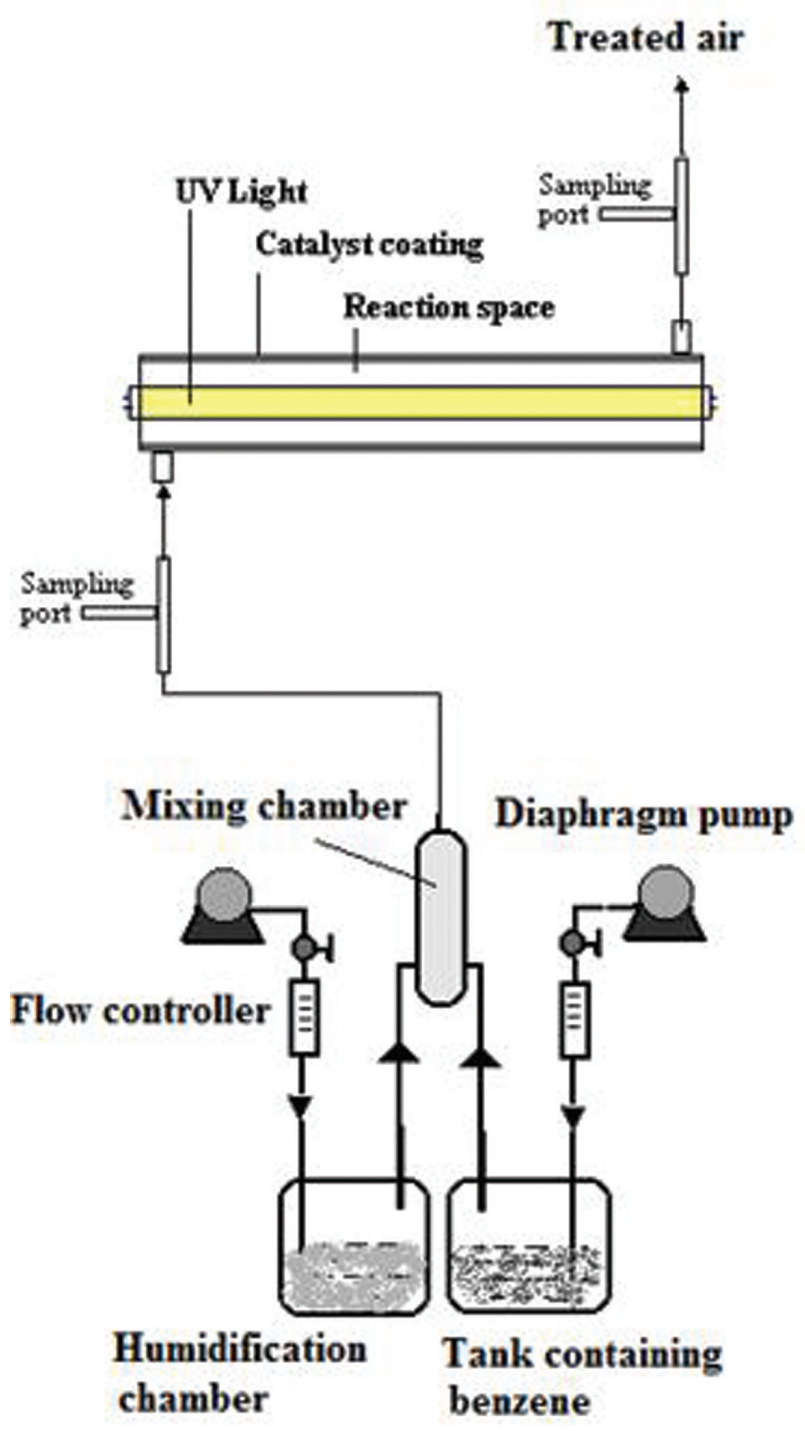

Fig. 1. Schematic of the photoreactor 


\subsection{Catalyst coating}

The catalyst was coated on the inner surface of the tubular reactor by introducing $10 \mathrm{ml}$ of ultra sonicated slurry of $20 \% \mathrm{TiO}_{2}$, closing both the ends and rotating the tube through a specially designed rotary mechanism at $10 \mathrm{rpm}$. Hot air blown through the end caps facilitated uniform drying. After 10 minutes coated $\mathrm{TiO}_{2}$ film was calcined in an oven for 8 hours at $200{ }^{\circ} \mathrm{C}$.

\subsection{Experimental conditions}

Benzene vapor and humidified air streams were generted by passing oil-free air through mini diaphragm pumps into bottles containing benzene and distilled water at room temperature. These were then mixed in a mixing chamber to produce a well humidified benzene stream. The saturated moist air stream at controlled flow rate was passed through a series of packed colums containing drying agents silica gel and calcium chloride dihydrate to get the required level of relative humidity. The inlet gaseous stream was passed through the reactor without illumination till an equilibrium adsorption is attained. After ensuring steady state, the lamp was turned on and gaseous samples from the inlet and outlet sampling port were analyzed at regular intervals. All the experiments were carried out at ambient temperature $\left(28 \pm 2{ }^{\circ} \mathrm{C}\right)$ and at a relative humidity of $55 \%$.

The performance of the photoreactor was evaluated in terms of removal efficiency which is the fraction of benzene removed by the system, as mentioned in Equation (1).

Removal efficiency, RE, \% $=100 \times\left(\mathrm{C}_{\mathrm{gi}}-\mathrm{C}_{\mathrm{go}}\right) / \mathrm{C}_{\mathrm{gi}}$

\subsection{Experimental scheme}

The $2^{k}$ factorial design provides the smallest number of runs with which ' $k$ ' factors can be studied in a more systematic manner. The three factors namely, benzene concentration, catalyst load and flow rate were investigated at two levels (low and high) and it was assumed that the response variable, namely removal efficiency is approximately linear over the range of the factor levels chosen. The statistical model for a $2^{\mathrm{k}}$ design would include $k$ main effects, $\left(\begin{array}{l}k \\ 2\end{array}\right)$ two factor interactions, $\left(\begin{array}{l}k \\ 3\end{array}\right)$ three factor interactions and one $k$-factor interaction. This exemplifies that, for a $2^{k}$ design the complete model would contain $2^{k}-1$ effects. The levels of the factors may be arbitrarily called 'low' and 'high' and denoted by ' - ' and ' + ' respectively. In this study, a 23 design consisting of three factors were chosen at their two levels. The experimental design consisted of combinations of main effects, viz., effect of inlet concentration (A), catalyst load (B) and flow rate (C) and interaction effects ' $\mathrm{AB}$ ', ' $\mathrm{AC}$ ', ' $\mathrm{BC}$ ' and ' $\mathrm{ABC}$ '. Besides, a suitable number of runs replicated by keeping the levels of variables at a center point (0) provided an estimate of the residual error associated with the experiments and also the curvature of the response. There were seven degrees of freedom between the eight combinations in the 23 design, i.e. three degrees of freedom associated with the main effects of A, B and C, three degrees of freedom associated with the interaction effects, and one associated with the interaction between ABC.

ANOVA was applied to estimate the effects of main variables and their potential interaction effects on benzene removal. An ANOVA table is given at the end of every statistical analysis.

\section{RESULTS AND DISCUSSION}

The effect of three influencing process parameters namely benzene concentration, catalyst load, and flow rate on the removal of benzene was studied in the annular tubetype photoreactor using $2^{k}$ factorial design approach. The design matrix with the ranges of parameters and the corresponding response, i.e., steady state removal efficiency of benzene is shown in Table 2. 
Tab 1 e 2

Full factorial design matrix of the three variables along with the observed response (RE \%) for gas-phase benzene removal

\begin{tabular}{cccccc}
\hline \hline $\begin{array}{c}\text { Run } \\
\text { order }\end{array}$ & $\begin{array}{c}\text { Catalyst load } \\
\left(\mathrm{g} \cdot \mathrm{m}^{-2}\right)\end{array}$ & $\begin{array}{c}\text { Benzene concentration } \\
\left(\mathrm{g} \cdot \mathrm{m}^{-3}\right)\end{array}$ & $\begin{array}{c}\text { Flow rate } \\
\left(1 \cdot \mathrm{min}^{-1}\right)\end{array}$ & $\begin{array}{c}\text { Residence time } \\
(\mathrm{s})\end{array}$ & $\begin{array}{c}\text { Removal efficiency } \\
(\%)\end{array}$ \\
\hline & & & & & \\
1 & 5 & 0.2 & 0.2 & 70 & 60.22 \\
2 & 20 & 0.2 & 0.2 & 70 & 95.51 \\
3 & 5 & 6 & 0.2 & 70 & 9.31 \\
4 & 20 & 6 & 0.2 & 70 & 11.63 \\
5 & 5 & 0.2 & 1 & 14 & 26.48 \\
6 & 20 & 0.2 & 1 & 14 & 62.28 \\
7 & 5 & 6 & 1 & 14 & 6.77 \\
8 & 20 & 6 & 1 & 14 & 10.55 \\
9 & 12.5 & 3.1 & 0.6 & 23.4 & 9.3 \\
10 & 12.5 & 3.1 & 0.6 & 23.4 & 9.7 \\
\hline \hline
\end{tabular}

\subsection{Main effects of parameters}

It can be observed that the benzene removal efficiency varied significantly depending on the inlet concentration, catalyst load and flow rate, ranging from $6.77 \%$ to $95.51 \%$. This indicates that some of the variables are highly significant in determining the rate of benzene removal in the photoreactor. The relative comparison of the effect of different parameters can be made from the main effects plot shown in Figure 2. It is clearly evident that changes in benzene concentration exhibits a greater effect on the removal efficiency of benzene than changes in either catalyst load or flow rate, and both of these parameters together. Also, it can be seen that the removal efficiency of benzene increases directly with the increase in the catalyst load, while there was a decrease in the removal efficiency with an increase in benzene concentration as well as flow rate. As the catalyst loading rate increases, the available active sites on the catalyst surface increases thereby more pollutants are adsorbed on the surface of catalyst leading to the higher removal of pollutants. Similar effect of catalyst on aqueous and gaseous benzene removal has been reported in the literature. Sirisuk et al. reported that conversion of ethylene increased with catalyst loading rate [8]. In yet another similar research, as reported by Wang et al., benzene removal rate in an optical fiber photoreactor increased significantly with an increase in $\mathrm{TiO}_{2}$ film thickness [2]. Lewandowski and Ollis showed that the photocatalytic degradation of benzene increased multi-fold due to an increase in the catalyst load [14].

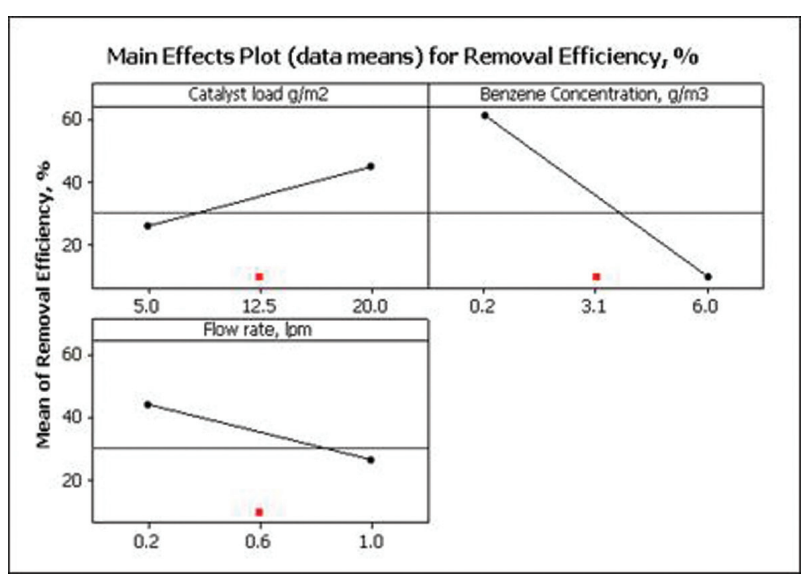

Fig. 2. Main effects plot for gas-phase benzene removal 
The results further delineated that higher initial concentration of benzene results in decreasing the removal of that pollutant. This phenomenon could be explained as follows: during photocatalytic oxidation, the available surface area of the catalyst becomes insufficient when excess pollutant molecules are present near the active sites, and that only partial oxidation could occur at that residence time. This decreasing removal profiles is consistent with literature reports [2, 15 and 16]. Anew, when the flow rate is lower, i.e. the residence time of the pollutants staying inside the photoreactor is more, yielding higher removal of pollutants and vice versa. Fu et al. observed similar results for the benzene photodegradation in an annular photoreactor [17].

\subsection{Magnitude and the importance of the effects}

Pareto chart provides valuable information about the magnitude and importance of main and interaction effects of process parameters on the response variable. This chart displays the absolute values of the effects, and draws a reference line on the chart. Any effect that extends past this reference line can be considered to be potentially important. From Figure 3 it is evident that individual and some binary interaction effects are

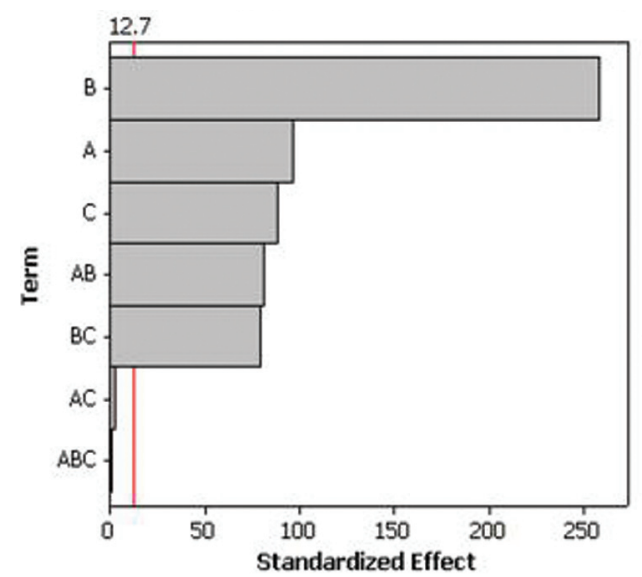

Fig. 3. Pareto plot showing the influence of process parameters for gas-phase benzene degradation (A-catalyst load, $\mathrm{g} / \mathrm{m}^{2} ; B$-Benxeme concentration, $\mathrm{g} / \mathrm{m}^{3}$; C-Flow rate lpm) potentially important. These results confirm that changes in the concentration of benzene have a greater effect on the removal of benzene than both catalyst loading rate and flow rate.

\subsection{Analysis of Variance}

The results of the factorial design also yielded the following regression equation for the benzene removal as shown in Equation (2).

$$
\begin{gathered}
\mathrm{Y}=9.66 x_{1}-25.79 x_{2}-8.84 x_{3}-8.11 x_{1} x_{2}+ \\
0.26 x_{1} x_{3}+7.91 x_{2} x_{3}+0.13 x_{1} x_{2} x_{3}+35.33
\end{gathered}
$$

The statistical analysis of the results in the form of ANOVA is shown in Table 3. ANOVA is required to test the significance and adequacy of the model. The Fischer variance ratio $(F)$, which is a statistically valid measure of the fitness of the model, can be calculated from the ANOVA table, by dividing the mean square due to model by the mean square value due to error. The greater the $F$ value from testing, more certain it is that the estimated factors are real.

The high $F$ values and low $\mathrm{P}$ values signify that the main effects and the 2-way interaction effects are highly significant in affecting the variations in removal of benzene. The significance of each coefficient and factor was determined by student $w$-test and $P$ values which are shown in Table 4 . The $P$ values were used as a tool to check up the significance of each coefficient and also to understand the pattern of mutual interactions between the test variables. The larger the magnitude of $T$ value and smaller the $P$ value, the more significance is the corresponding coefficients. Among the main effects on removal of benzene, benzene concentration $(T=-286.57, P=$ $0.002)$ appears to play a major role than catalyst loading rate $(107.35,0.006)$ and flow rate $(-98.18,0.006)$. This is in accordance with the results shown by the Pareto chart shown in Figure 3. 
Table 3

ANOVA table for gas-phase benzene removal

\begin{tabular}{lcrrrrc}
\hline \hline Source & DF & Seq SS & Adj SS & Adj MS & \multicolumn{1}{c}{$F$} & $P$ \\
\hline Main effects & 3 & 6692.86 & 6692.86 & 2230.95 & 30000 & 0.004 \\
2-Way interactions & 3 & 1026.94 & 1026.94 & 342.31 & 5000 & 0.010 \\
3-Way interactions & 1 & 0.14 & 0.14 & 0.14 & 2.13 & 0.383 \\
Residual error & 1 & 0.06 & 0.06 & 0.06 & & \\
Pure error & 1 & 0.06 & 0.06 & 0.06 & & \\
\hline \hline
\end{tabular}

Table 4

\section{T and $P$ values from ANOVA for gas-phase benzene removal}

\begin{tabular}{lrcrc}
\hline \hline Term & Effect & Coefficient & \multicolumn{1}{c}{$T$} & $P$ \\
\hline Constant & & 35.33 & 392.57 & 0.002 \\
$x_{1}$ & 19.32 & 9.66 & 107.35 & 0.006 \\
$x_{2}$ & -51.58 & -25.79 & -286.57 & 0.002 \\
$x_{3}$ & -17.67 & -8.84 & -98.18 & 0.006 \\
$x_{1} \times x_{2}$ & -16.22 & -8.11 & -90.12 & 0.007 \\
$x_{1} \times x_{3}$ & 0.52 & 0.26 & 2.88 & 0.213 \\
$x_{2} \times x_{3}$ & 15.81 & 7.91 & 87.85 & 0.007 \\
$x_{1} \times x_{2} \times x_{3}$ & 0.26 & 0.13 & 1.46 & 0.383 \\
\hline \hline
\end{tabular}

A comparison between the experimental and model predicted values of benzene removal is shown in Figure 4. The nearly perfect fit clearly demonstrates the predictability of the model equation.

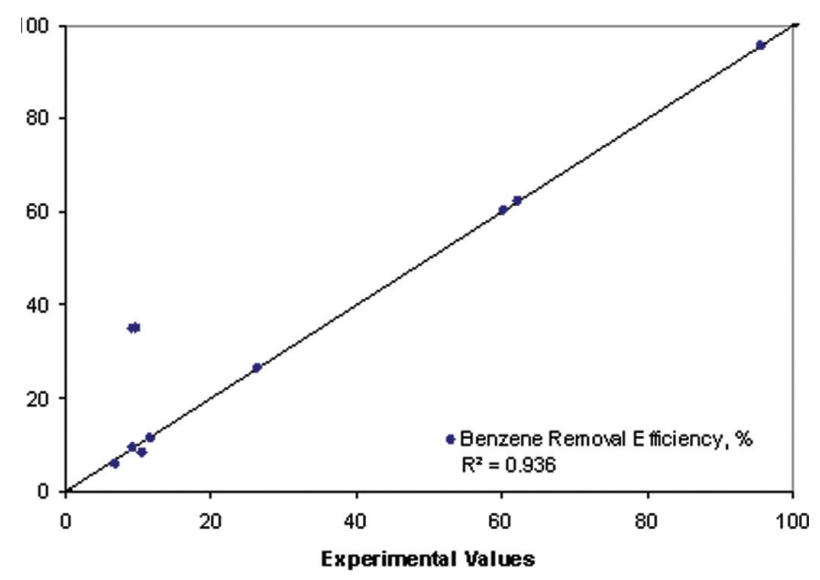

Fig. 4. Comparison between predicted and experimental gas-phase benzene removal efficiency from model equation

\section{CONCLUSION}

Studies on gas-phase benzene removal by photodegradation in an annular tube photoreactor by a 23 factorial design approach yielded statistically significant main effects plot, Pareto plot and a regression model equation for benzene removal. The maximum removal efficiency of benzene was found to be 95.51 $\%$ for an inlet concentration of $0.2 \mathrm{~g} / \mathrm{m}^{3}$ and a catalyst load of $20 \mathrm{~g} / \mathrm{m}^{2}$ and at a flow rate of $0.21 \cdot \mathrm{min}^{-1}$. The main effects plot revealed that the changes in benzene concentration have a greater effect on the removal efficiency of benzene than changes caused due to variations in catalyst load and flow rate. From the Pareto plot, the magnitude and importance of the main and interaction effects of parameters follow the order benzene concentration $>$ catalyst load $>$ flow rate $>$ catalyst load $\times$ benzene concentration $>$ benzene concentration $\times$ flow rate. The results from this study would 
provide a strong fundamental understanding in applying the concept of photocatalysis in industrial situations.

Acknowledgements. The authors would like to thank and acknowledge the support in terms of research funds received from the Swedish International Development Agency (SIDA) under the Project grant No: CHE/01-02/054/SIDA/DVSM.

\section{List of nomenclatures, abbreviations and symbols}

Adj MS - Adjusted mean squares

Adj SS - Adjusted sum of squares

ANOVA - Analysis of variance

CAAA - Clean Air Act Amendments

$\mathrm{C}_{\mathrm{gi}}-$ Inlet benzene concentrations, ppmv

$\mathrm{C}_{\mathrm{go}}^{\mathrm{gi}}$ - Exit benzene concentrations, ppmv

$\mathrm{DF}$ - Degrees of freedom

$\mathrm{F}$ - Fischer's variance ratio

$P$ - Probability value

RE - Removal efficiency

Seq SS - Sequential sum of squares

SIDA - Swedish International Development

Agency

$T$ - Student $t$-test value

USEPA - United States Environmental Protection Agency

UV - Ultra Violet

VOC - Volatile Organic Compounds

$x_{1}$ - Catalyst load $\left(\mathrm{g} \cdot \mathrm{m}^{-2}\right)$

$x_{2}$ - Benzene concentration $\left(\mathrm{g} \cdot \mathrm{m}^{-3}\right)$

$x_{3}$ - Flow rate $\left(1 \cdot \mathrm{min}^{-1}\right)$

$\mathrm{Y}$ - Benzene removal efficiency (\%)

\section{REFERENCES}

[1] Minnesota Department of Health Fact Sheet, March 2004, www.health.state.mn.us/divs/eh/air.

[2] W. Wang, L.W. Chiang, Y. Ku, Decomposition of benzene in air streams by $\mathrm{UV} / \mathrm{TiO}_{2}$ process, $\mathrm{J}$. $\mathrm{Ha}$ zard. Mater. B101, 133-146 (2003).

[3] Z. Pengyi, L. Fuyan, Y. Gang, C. Qing, Z. Wanpeng, A comparative study on decomposition of gaseous toluene by $\mathrm{O}_{3} / \mathrm{UV}, \mathrm{TiO}_{2} / \mathrm{UV}$ and $\mathrm{O}_{3} / \mathrm{TiO}_{2} / \mathrm{UV}$, J. Photochem. Photobiol. A: Chem. 156, 189-194 (2003).

[4] D.F. Ollis, H. Al-Ekabi, in: Photocatalytic Purification and Treatment of Water, 481-494, Elseiver, Am- sterdam, The Netherlands, 1993

[5] R.M. Alberici, W.F. Jardim, Photocatalytic destruction of VOCs in the gas-phase using titanium dioxide, Appl. Catal. B: Environ. 14, 55-68 (1997).

[6] O. d'Hennezel, P. Pichat, D. F. Ollis, Benzene and toluene gas-phase photocatalytic degradation over $\mathrm{H}_{2} \mathrm{O}$ and $\mathrm{HCl}$ pretreated $\mathrm{TiO}_{2}$ : by-products and mechanism, J. Photochem. Photobiol. A: Chem. 118, 197-204 (1998).

[7] X. Deng, Y. Yue, Z. Gao, Gas-phase photo-oxidation of organic compounds over nanosized $\mathrm{TiO}_{2}$ photocatalysts by various preparations, App. Catal. B:Environ. 39, 135-147 (2002).

[8] C.G. Sirisuk, Jr. Hill, M. A. Anderson, Photocatalytic degradation of ethylene over thin films of titania supported on glass rings, Catal. Today 54, 159-164 (1999).

[9] S. Hager, R. Bauer, Heterogeneous photocatalytic oxidation of organics for air purification by near UV irradiated titanium dioxide, Chemosp. 38, 1549-1559 (1999).

[10] J. Jeong, K. Sekiguchi, K. Sakamoto, Photochemi$\mathrm{cal}$ and photocatalytic degradation of gaseous toluene using short-wavelength $\mathrm{UV}$ irradiation with $\mathrm{TiO}_{2}$ catalyst: comparison of three UV sources, Chemosp. 57, 663-671 (2004).

[11] O.H. Park, C.S. Kim, Experimental study on the treatment of volatile organic compound vapors using a photoreactor equipped with photocatalyst-coated fabrics, J. Appl. Pol.Sci. 91, 3174-3179 (2004).

[12] M. Mohseni, A. David, Gas-phase vinyl chloride oxidation using $\mathrm{TiO}_{2}$-based Photocatalysis, App. Catal. B: Environ. 46, 219-228 (2003).

[13] D. C. Montgomery, Design and Analysis of Experiments, 3rd ed., Wiley, New York, 1991.

[14] M. Lewandowski, D.F. Ollis, A Two-site kinetic model simulating apparent deactivation during photocatalytic oxidation of aromatics on titanium dioxide $\left(\mathrm{TiO}_{2}\right)$, App. Catal. B: Environ. 43, 309-327 (2003).

[15] N.N. Lichtin, M. Sadeghi, Oxidative photocatalytic degradation of benzene vapor over $\mathrm{TiO}_{2}, J$. Photochem. Photobiol. A: Chem. 113, 81-88 (1998).

[16] J.H. Wang, M.B. Ray, Application of ultraviolet photooxidation to remove organic pollutants in the gas phase, Sep. Puri.Tech. 19, 11-20 (2000).

[17] X. Fu, W.A. Zeltner, M.A. Anderson, The gas-phase photocatalytic mineralization of benzene on porous titania-based catalysts, App. Catal. B: Environ. 6, 209-224 (1995). 